\title{
Biographical appendix
}

\begin{abstract}
Amery, Leopold (1873-1955). Unsuccessful candidate for East Wolverhampton, 1906, 1908, January 1910; Bow and Bromley, December 1910; Unionist MP for Sparkbrook, Birmingham, 1911-18; South Birmingham 1918-45. War service in Europe, 1914-16; deputy secretary to the War Cabinet, 1917-19; parliamentary under-secretary at Colonial Office (under Viscount Milner) 1919-21; parliamentary secretary for the Admiralty, 1921-22; first lord of the Admiralty 1922-24; colonial secretary 1924-29. Supporter of National Service League; founder of British Covenant campaign; chairman of Tariff Reform League management committee; stopped active work with the TRL after autumn 1917.
\end{abstract}

Atholl, Duchess of (Katharine Stewart-Murray, 1874-1960). Marchioness of Tullibardine between 1899 and 1917; husband was Unionist MP for West Perthshire, January 1910-17, inherited dukedom in 1917. President of Perthshire Women's Unionist Association, 1908-18; supporter of National League for Opposing Women's Suffrage; war work in Egypt; Unionist MP for Kinross and West Perthshire, 1923-38; first woman to serve in a Conservative government as parliamentary secretary to the Board of Education, 1924-29.

Bottomley, Horatio (1860-1933). Liberal MP for Hackney South, London 1906-10; retained seat as an independent in December 1910; expelled from parliament when found bankrupt in 1912; independent MP for Hackney South, 1919-22. Founded John Bull newspaper in 1906; prominent recruitment speaker during the First World War; played active role in the by-election campaigns of several independent candidates during 1916-18; supported anti-waste candidates during 1919-21; found guilty of fraud in 1922, expelled from parliament and spent five years in gaol.

Bridgeman, Caroline (née Parker, 1873-1961). Wife of William Bridgeman, who served as Unionist MP for Oswestry, Shropshire, 1906-29, home secretary, 1922-24, first lord of the Admiralty, 1924-29. Founded Oswestry Women's Unionist Association in 1904; vice-chairman of Women's Unionist and Tariff Reform Association; member of British Women's Covenant committee; involved in work of Women's Land Army during the First World War; chairman of Women's Unionist Organisation, 1918-25 and National Union of Conservative Associations, 1926-27; retired from political life simultaneously with her husband in 1929.

Chamberlain, Anne (1883-1967). Wife of Neville Chamberlain. President of Ladies Committee of the Birmingham Navy League from 1915; founded Unionist Women's Institute movement in 1919; president of Ladywood, Birmingham Women's Unionist Association and West Midlands Women's Unionist Organisation from 1918. 
Derby, Lord (Edward Stanley, seventeenth Earl of Derby, 1865-1948). Known as Lord Stanley until he succeeded to the peerage in 1908. Conservative MP for West Houghton, Lancashire, 1892-1906; president of Liverpool Workingmen's Conservative Association (Archibald Salvidge served as the association's chairman); opponent of tariff reform, played important role in precipitating crisis which led to Bonar Law memorial of 1913; director-general of recruiting, 1915-16; secretary of state for war, 1916-18; British ambassador to France, 1918-20.

Fisher, Victor (1870-1954). Member of the Fabian Society and Social Democratic Federation (later British Socialist Party) during the Edwardian period; co-founded Socialist National Defence Committee in 1915; this formed the basis of the British Workers League, which Fisher served as honorary secretary, 1916-18. Edited British Citizen and Empire Worker, 1916-18; ended active work for BWL around the time of the 1918 general election. Unsuccessful contests in Stourbridge, Worcestershire, National Democratic Party (BWL), 1918; West Ham, London, Conservative, 1923.

Goulding, Edward (1862-1936, appointed Baron Wargrave, 1922). Unionist MP for Devizes, Wiltshire, 1895-1906; City of Worcester, 1908-22. Chaired Tariff Reform League organisation committee, 1905-13; chairman of Rolls Royce from 1921.

Hannon, Patrick (1871-1963). Unsuccessful contests, East Bristol, January and December 1910; Unionist MP for Moseley, Birmingham, 1921-50. Acted as a vicepresident of the Tariff Reform League, 1910-14; Navy League general secretary, 1911-18; director of British Commonwealth Union, 1918-23.

Lyttelton, Edith (née Balfour, 1865-1948). Wife of Alfred Lyttelton. Honorary secretary of the Victoria League; supporter of Liberal Women's Unionist Association and Women's Unionist and Tariff Reform Association; served on executive of National Union of Women Workers; involved in Help the Ulster Women campaign; founder of War Refugees Committee in 1914; appointed deputy director of women's branch of the Ministry of Agriculture in 1917; British substitute delegate to the League of Nations Union, 1923, 1926-28, 1931.

Maxse, Mary (née Wyndham, 1870-1944). Chairman of Women's Tariff League, 1905-6 and Women's Unionist and Tariff Reform Association, 1906-18. Wartime work for agricultural and pensions committee and the Women's Institutes.

Northcliffe, Viscount (Alfred Harmsworth, 1865-1922). Unsuccessful candidate for Portsmouth, 1895; brother of Viscount Rothermere. Began publication of the Daily Mail in 1896 and the Daily Mirror in 1903; purchased The Times in 1908. Supported independent candidates during 1916 by-elections; director of propaganda, 1917-18. Northcliffe's papers supported the Anti-Waste League's campaigns in the early 1920s.

Page Croft, Henry (1881-1947). Unsuccessful contest, Lincoln, 1910; Conservative MP for Christchurch, Hampshire, 1910-18; Bournemouth, Hampshire, 1918-45 (1918-22 as National Party member); Tariff Reform League organising committee vice-chairman, 1913-16, chairman 1916-17. War service in France, 1914-16; founded National Party in 1917, severing relations with Conservative Party and TRL; returned to the Conservative Party in 1921; chairman of Empire Industries Association. 
Pemberton-Billing, Noel (1881-1948). Unsuccessful contest, Mile End, London, January 1916 and four by-elections during 1941; independent MP for Hertford, March 1916-21. Formed Vigilante Party in 1917, ran candidates at wartime by-elections in Clapham and East Finsbury, London. Keen critic of government air policy during the First World War; unsuccessfully sued by Maud Allen for libel. Made lurid allegations about the sexual 'perversions' of public figures in court during summer 1918; forcibly removed from House of Commons in July 1918 for disregarding the authority of the chair.

Rothermere, Viscount (Harold Harmsworth, 1868-1940). Brother of Viscount Northcliffe. Worked with Northcliffe to establish Daily Mail and Daily Mirror; acquired Sunday Pictorial in 1915; founded Anti-Waste League in 1921.

Smedley-Crooke, James (1861-1951). MP for Deritend, Birmingham, 1924-29, 1931-45; honorary treasurer of Midland Division of Comrades of the Great War; involved in Birmingham British Legion and Digbeth Institute.

Willoughby de Broke, Lord (Richard Greville Verney, 1869-1923). MP for Rugby, 1895-1900; president of Imperial Maritime League; founded League for the Support of Ulster in 1912. 